\title{
Constructing an Entrepreneurial Life Liminality and Emotional Reflexivity in Identity Work
}

Muhr, Sara Louise; De Cock, Christian; Twardowska, Magdalena; Volkmann, Christina

Document Version

Accepted author manuscript

Published in:

Entrepreneurship and Regional Development

DOI:

10.1080/08985626.2019.1596348

Publication date:

2019

License

Unspecified

Citation for published version (APA):

Muhr, S. L., De Cock, C., Twardowska, M., \& Volkmann, C. (2019). Constructing an Entrepreneurial Life:

Liminality and Emotional Reflexivity in Identity Work. Entrepreneurship and Regional Development, 31(7/8), 567-

582. https://doi.org/10.1080/08985626.2019.1596348

Link to publication in CBS Research Portal

\section{General rights}

Copyright and moral rights for the publications made accessible in the public portal are retained by the authors and/or other copyright owners and it is a condition of accessing publications that users recognise and abide by the legal requirements associated with these rights.

Take down policy

If you believe that this document breaches copyright please contact us (research.lib@cbs.dk) providing details, and we will remove access to the work immediately and investigate your claim. 


\section{Constructing an Entrepreneurial Life: Liminality and Emotional Reflexivity in Identity Work}

\section{Sara Louise Muhr, Christian De Cock, Magdalena Twardowska, and Christina Volkmann}

Journal article (Accepted manuscript*)

\section{Please cite this article as:}

Muhr, S. L., De Cock, C., Twardowska, M., \& Volkmann, C. (2019). Constructing an Entrepreneurial Life: Liminality and Emotional Reflexivity in Identity Work. Entrepreneurship and Regional Development, 31(7/8), 567-582. https://doi.org/10.1080/08985626.2019.1596348

This is an Accepted Manuscript of an article published by Taylor \& Francis in Entrepreneurship and Regional Development on 06 Apr २०19, available online:

DOl: http://www.tandfonline.com/10.1080/08985626.2019.1596348

* This version of the article has been accepted for publication and undergone full peer review but has not been through the copyediting, typesetting, pagination and proofreading process, which may lead to differences between this version and the publisher's final version AKA Version of Record. 


\section{Constructing an Entrepreneurial Life:}

\section{Liminality and Emotional Reflexivity in Identity Work}

Sara Louise Muhr ${ }^{1}$, Copenhagen Business School, $\underline{\text { slm.ioa@cbs.dk }}$

Christian De Cock, Copenhagen Business School, $\underline{\text { cdc.ioa@cbs.dk }}$

Magdalena Twardowska, Standard Chartered Bank, Hong Kong.

Christina Volkmann, University of Essex, c.r.volkmann@essex.ac.uk

${ }^{1}$ Department of Organization, Kilevej 14A, 2000 Frederiksberg, Denmark 


\title{
Constructing an Entrepreneurial Life:
}

\section{Liminality and Emotional Reflexivity in Identity Work}

\begin{abstract}
This paper examines the identity work of a budding entrepreneur through a longitudinal case study based on his ongoing personal reflections as he tries to construct an entrepreneurial life. In particular, we investigate the role of emotional reflexivity and liminality, concepts that give us analytical purchase in exploring the complex dynamics of this identity work. The liminal condition of multiple identity positions enables our informant to experiment with and integrate several parallel identity narratives as he tries on socio-political constructions of 'the entrepreneur' for size; and it is the permanence of the liminal condition that makes emotional reflexivity necessary so he can handle the constant lack he experiences. The contribution of our work lies in exploring how the operation of the discourse of enterprise never closes on the centre of subjectivity that is imputed in that discourse, and how our subject, through emotional reflexivity, deals with this fundamental lack.
\end{abstract}




\section{Introduction}

Our study aims to engage the topic of the 'socio-political' by examining how the consequences of the discourse of entrepreneurship play out in the dynamic identity work of a single individual who is trying on for size culturally stereotypical constructions of the entrepreneurial persona which sweep together 'a miscellaneous grouping of attributes and actions as an entrepreneurial rubric' (Anderson and Warren 2011, 605). The excitement and the enticements of this enterprise discourse inevitably produce identities which are full of paradoxical tensions (Daskalaki et al. 2015) when life means 'always being on the way to somewhere else' (Sørensen 2008, 91). This entrepreneurial life can thus be considered as a permanent liminal state of being 'in-between' (Anderson 2005; Steyaert 2005) where 'identities are continuously contested and in flux' (Clarke and Holt, 2017, 479). Following recent work exploring how entrepreneurial actors reconcile the representation of the self embedded in discourses of entrepreneurship - and its associated notions of independence and excitement (Larty and Hamilton 2011; Watson 2013a) - with the often-messy reality of entrepreneurial life (Clarke and Holt 2010, Gartner, 2010), we detail here the constant negotiation of various experienced possible selves in one specific case. We specifically aim to explore the dynamic role emotional reflexivity plays in identity work within a more or less permanent liminal condition of entrepreneurial action (Daskalaki et al. 2016; Johnsen and Sørensen 2014; Steyaert, 2005) and do so by focusing on the emotional ups-and-downs of one individual (whom we have called Robert - a pseudonym) through a longitudinal study, drawing on eighteen months' worth of his email correspondence with one of the authors.

Building on Burkitt's (2012) notion of 'emotional reflexivity', our analysis focuses on the way Robert uses emotions as a way for him to be self-reflexive. Our paper in this way provides empirical knowledge on the way emotions are an integrative part of reflexive identity work and 
not simply an outcome of successful or failed identity work as much of the literature on emotions seems to suggest (e.g. Conroy and O’Leary-Kelly, 2014). Emotional reflexivity offers the opportunity for Robert to struggle with entrepreneurship discourse and the desire it evokes in him to construct his identity in relation to this discourse. As such the contribution of our work lies in exploring how the operation of the discourse of enterprise never closes on the centre of subjectivity that is imputed in that discourse, and how Robert, through emotional reflexivity, deals with this fundamental lack.

What is at stake, then, is not so much the content of norms and ideals embodied in a particular discourse so much as the mode of the subject's engagement with these norms and ideals (Glynos and Stavrakakis 2008). Whilst the subject is not strictly a subject in that a stable identity is never reached, the object of enterprise discourse is itself lacking in that it alwaysalready fails in filling the lack in the subject. This discourse "presents a quasi-explanation and a demonstration, but one drained of specificity' (Drakopoulou Dodd et al. 2013, 71), and as Jones and Spicer $(2005,236)$ suggest in a colourful turn of phrase, rather than providing a stable centre, 'entrepreneurship discourse is... a paradoxical, incomplete and worm-ridden symbolic structure that posits an impossible and indeed incomprehensible object at its centre'. This lack in both object and subject cannot but lead to identity work under permanent liminal conditions where the subject tries on multiple selves, 'haunted by the ever-present, fatiguing shame of failure, inadequacy, and not making the most of one's potential and using one's life in the most productive way' (Catlaw and Marshall 2018, 105).

In what follows we will first outline our key concepts of identity work, liminality and emotional reflexivity. We will then sketch the research context and expand on our method and analytical strategy before we delve into Robert's emails. These offer a 'slice of life' in a single 
entrepreneurial setting and show how emotional reflexivity can somehow suture together various contradictions and challenges found in parallel identity narratives.

\section{Identity, identity work and liminality}

Identity has long been used as a term to understand entrepreneurial experiences, struggles and meaning-making (Egan-Wyer et al. 2018; Jarvis 2016; Kašperová and Kitching 2014). In a key text in the entrepreneurship literature, Gartner (1988) demonstrated, for example, that the question 'who is an entrepreneur?' is based on erroneous assumptions about stable identities. Meanwhile a multitude of studies in the organization studies literature have taken as a key concern the various ways in which individuals interact with broader societal discourses (e.g. Alvesson and Willmott 2002; Coupland and Brown 2012). These studies have aimed to capture the complexity of such interaction, resulting in a body of research which sees identity as a 'temporary, context-sensitive and evolving set of constructions' (Alvesson et al. 2008, 6). Common in these literatures, in more or less explicit ways, is the argument that there is no 'fixed', 'true' or 'authentic' kernel of the self, and that the individual is a feeling and reflecting self who continuously negotiates and renegotiates preferred versions of self under the influence of socio-political structures and discourses (Alvesson et al. 2008; Beech 2008; Holmes 2010; Muhr et al., 2012).

To develop the notion that identity is not just an inner state formed by an autonomous individual but is always-already political through the regulatory dynamics of societal structures and discourses, the term identity work has been coined (Alvesson and Willmott 2002). It captures the way in which an individual constantly engages in a reflexive practice of negotiating own opinions, experiences and macro influences on changing perceptions of self. According to Beech $(2008,53)$ it is in the dialogue between self and context that we negotiate the meanings 
we attach to things. People are therefore not just 'passive recipients of discourses' as pointed out by Thomas and Davies (2005, 700), but both resist and incorporate them in multiple and sometimes ambiguous ways. Individuals craft self-narratives by drawing on cultural resources embedded in their social, political and historical context in order to reproduce or transform their sense of self (Hamilton 2014; Thomas 2009). Such a self-narrative can potentially consist of several fragmented selves, where preferred versions of self are not clear, but rather depend on the context, making one perception of self not necessarily more true or false than another (Costas and Fleming 2009). Such possible selves may act both as ideal selves representing wished-for identities bearing most valued characteristics or indeed as identity threats where they represent identity positions which are classified as 'non-me' positions (Thomas 2009). They highlight the temporary nature of identities and their intrinsic orientation towards the future in the form of constant negotiation between what is and how we would like to be. Possible selves are thus elaborated through a sense-making process into which we incorporate a multiplicity of identity positions present within one subject (Beech 2008).

In order to explore the processes underlying this processual view on identity work in which subjects experience and negotiate changing identities, we turn to writings on the concept of liminality (Beech 2011; Conroy and O’Leary-Kelly 2014). Here, we find an examination of how radical identity shifts necessitate new identity positions, which must be supplemented by a certain rite of passage that re-establishes meanings. Liminality is a notion originally used by anthropologists (van Gennep 1960) to consider such transitions achieved in rituals and ceremonies, where subjects pass from a pre-ceremonial to a new state, by passing through the liminal. According to van Gennep, identities change in three stages: separation (during which a person symbolically detaches from their previous identity), liminality (which he defines as an in-between stage of neither here nor there), and aggregation (which concludes the liminal 
period by constructing a new identity). Liminality thus refers to the ambiguity experienced by an actor who has left her pre-ritual status but has not yet gained the status that she will hold once the ritual is over (Daniel and Ellis-Chadwick 2016). Liminality, however, as has been argued first by Turner (1977) and later more explicitly in relation to modern work-life by Johnsen and Sørensen (2014), is not necessarily a temporary state, but can also be conceived as a 'more lasting experience of ambiguity and in-betweenness' (Daskalaki et al. 2016, 186) which remains unredeemed.

Turner $(1977,95)$ further extended the earlier work on liminality by proposing to look at liminality 'betwixt and between the positions assigned and arrayed by law, custom, convention and ceremonial', emphasizing its interstructural aspect. For Turner (1967), liminality can be seen as an anti-structure where the emphasis is not so much on destruction of the old but a space for possibility, closely tied to the notion of 'communitas' which can be interpreted as a social context which is ready to accept the new identity. The creative aspect of liminality is thus tied to the notion of temporal experimentation of new attachments that follows disidentification from the previous identity. This transformation is possible because the liminal is unbound from the customary, changing the unsettling into the creative and sometimes resulting in a 'period of acute identity conflict' (Ibarra 2007, 23). However, as Turner $(1974,59)$ also stresses, a subject may suffer from 'symbolic stress' due to the feeling of lost identity that liminality can cause. In the organization studies literature Beech (2011), Czarniawska and Mazza (2003), Daskalaki et al. (2016), and Johnsen and Sørensen (2014) have picked up on this, and emphasize that because of high levels of conflict within the self, liminal experiences will necessarily be stressful ones, mobilizing various emotions: from exhilaration to extreme frustration. 


\section{Connecting emotional reflexivity, liminality and identity work}

Historically the study of emotions in an identity context favoured a view where emotions are seen as interruptions to rationality (Lemmergaard and Muhr 2013; Mumby and Putnam 1992). In recent years, however, we have witnessed a shift towards emotions conceived of as something that can be utilized and controlled for organizational gain through an orientation at functional outcomes in identity development (Stets 2012). In this view, certain emotions are said to be mobilized to construct 'better' and 'stronger' identities, and identity construction is here seen as tied to certain emotions in patterned ways among other things as 'emotion regulation' (Conroy and O’Leary-Kelly 2014).

An emerging body of research is beginning to assess critically the rational perspective on emotions in organizational life, breaking away from the functionalist assumption that sees emotions as stimuli, in favour of an emergent view where emotions arise as part of interactions. This view corresponds with our critical view on identity where there is no fixed and permanent and hence no 'better' self. We align ourselves with those identity researchers who connect to the emotions literature by analysing individual strategies of negotiating emotions and perceptions of self in relation to workplace and societal discourses (e.g. Holmes 2010; Lemmergaard and Muhr 2012). Emotion work, then, becomes about situating oneself in social structures, as 'emotion is always situated' involving 'the whole person' rather than 'an isolatable aspect or attribute of a person's body or psychology' such as cognition, attitudes or personality (Barbalet 1998, 79). This is an important point because the involvement of the 'whole person' means that even the agentic consciousness of the self will be dependent on emotions, producing and reproducing social context, identities, and practices in an emotional way. In the context of liminality, emotions can thus mobilize promises and hopes about new selves through offering a feeling of possibility of agency and capability. However, these 
possible selves need to compete with other alternatives as well as being contested and regulated by various social influences. Possible selves will therefore somehow remain unrealised resulting in anger, agitation or resignation (Conroy and O'Leary-Kelly 2014). It is this negotiation process that is then manifested through the experience of an 'emotional rollercoaster' (Schaefer and Paulsson 2013), which in turn further influences the individual's identity work. Yet, while several researchers (e.g. Czarniawska and Mazza 2003; Ibarra 2007) have acknowledged the significant emotional impact of finding oneself in a liminal space, there has been little discussion in the literature on how emotions are an integrative part of the identity process.

Understood from the critical perspective outlined above, emotions become key to the reflexive process which influences identity work. They have a crucial role in the way we perceive ourselves and the social world around us. The notion of emotional reflexivity emphasizes that the relationship between emotions and identity is not that of a monitoring emotional response or action, but that emotions inform the reflexive process of identity construction through selfinterpretation (Burkitt 2012). That, in turn, is seen as the essential nature of dialogical identity construction (Beech 2008). However, this process is rarely unproblematic as Burkitt (2012, 468) suggests:

We are all 'fractured reflexives' to some degree. Either the knowledge we have about the situation we face is imperfect, or expert systems have failed us, or we are experiencing a powerful emotion that is colouring our reflexive view of ourselves, our actions, and our world to a large degree. Even those of us who feel ourselves to be sailing on calm emotional waters may be unaware that, beneath our reflexive understanding, the sea of feelings may be a bit more choppy than we think. 
In this quote Burkitt invites us to look at how the reflexive process negotiates the imperfect knowledge of, and necessary lack of control over, social context. He further argues that the emotional responses stemming from our evaluation will trigger a reflexive process as we reevaluate our identities in the changing setting. It is in this way that Burkitt's notion of emotional reflexivity can help us understand the liminal process. The key point here is that emotional reflexivity is not just reactive, but actually informs the process and has a direct influence on how identity is shaped.

If emotional reflexivity is central for identity work, reflexive empirical accounts become paramount in being able to construct a meaningful conceptual understanding of emotionally informed identity work. In what follows, we will explore such an account in the email diary of Robert, an entrepreneur in his late thirties, who reported thoughts about his business ventures to one of the authors over an eighteen-month period. In contrast to a tradition where informants tell the story of their lives, "rehearsing tales about how they "became" entrepreneurs and, by extension, what it means to "be" an entrepreneur' (Williams 2010, 16), Robert tells us his story as it unfolds and on his own initiative, thus giving us a unique insight into 'identity-work-asprocess' (Leitch and Harrison 2016, 187). His account highlights the on-going struggles and contradictions characterising liminality that in a more traditional retrospective narrative, focusing how the hero-entrepreneur transforms from one state to another, might have been dismissed as unimportant, or simply ignored.

\section{Research context and method}

After completing an MBA at a UK university, Robert started his own business. As part of a project which aimed to follow the development of his prime business idea - a mathematical model that could be sold to insurance companies, from now on called AMA - Robert wrote 
regular emails to one of the authors. However, AMA never became a great success, so Robert relied on other ventures, such as reselling other systems or consulting work, to earn a living (and making a significant amount of money in the process). All the emails are in one way or another centred on his struggle to make AMA a success. These emails effectively form a virtual diary containing rich self-narratives that offer a 'phenomenology of being in business' (Popp and Holt 2013, 66). Throughout this diary Robert made explicit the thoughts he was having as he tried to negotiate the place of his venture in his life. As Robert put it in an interview with us, 'it's difficult; it's a very personal thing because it is my business. I've got a lot of me and my future invested in it'. Central to his reflections are the struggles between the reality Robert experiences as someone who makes a living out of ventures not related to his own invention, and his preferred notion of self as portrayed in existing social representations of the entrepreneur. Robert's identity work can be seen to take place in this ever-present dialectic. It is the idea of entrepreneurial action - 'the making of adventurous, creative or innovative exchanges (or “deals”)' (Watson 2013b, 407) - which seems to regulate Robert's preferred identity.

I really struggle trying to define what I do... I like doing deals, not particularly interested in the money but I like doing deals... I've always been able to make money and have always enjoyed it; it never struck me as entrepreneurial, I didn't have any concept of what entrepreneurial was... I'm sure it's not the money, it's clinching the deal, it's actually saying, yes I've got something, I've made something, I've created something, and then somebody actually wants to buy that, I really like that, it's just fantastic! (Interview extract).

The empirical material that forms the basis of our analysis consists of 72 emails written over a period of 18 months which run over 150 pages when printed out. Whilst such a focus on an in- 
vivo entrepreneurial narrative and everyday events in the life of the entrepreneur is not unique ${ }^{2}$, what is unusual are the rich data in these emails on the role emotional struggles play in identity work. The data we collected were not used for their original purpose - that of tracking the establishment of the AMA business venture - and as the months went by it became clear that Robert simply enjoyed using the researcher as a sounding board to express his thoughts and feelings about the business, even if, and possibly because, the original new venture idea never really came to fruition ${ }^{3}$. In addition to the e-mails we conducted five interviews with Robert: one before the project, three during the process, and one at the end. Although not prominent in our analysis, the interviews added further context to the data and reduced the possibility of misinterpretation as they gave us an opportunity to inquire further into and clarify sections of the emails.

\section{Analytical strategy}

The diary entries were not structured following specific requests from the researcher. Rather, they ended up being a very fragmented account with Robert's single person perspective the

\footnotetext{
${ }^{2}$ To mention just one famous case, the book The Republic of Tea: The Story of the Creation of a Business, as Told Through the Personal Letters of Its Founders (Ziegler et al. 1994) relates a sequence of events and actions over a twenty-month period as the founders exchanged faxes with each other. But as Williams (2010, 16-17) suggests, precisely because the authors follow the typical narrative pattern - what Popp and Holt $(2013,53)$ referred to as 'the teleological drive to narrative studies' - that moves the protagonists 'through various challenges, villains and decision points on their way to the successful venture... the actual narrative itself isn't very interesting.'

${ }^{3}$ For example, one of Robert's emails starts with the ludic salutation 'Dear Psychotherapist'. However, the interaction was not always so playful and easy-going. In an email sent a few weeks later, in response to the rather neutral question 'What's new?' Robert snapped back, 'I'm under enough pressure without having to do "stuff" to make your research better!'
} 
element holding these narrative fragments together in a sequential, albeit sometimes erratic, unfolding. At no point was Robert specifically encouraged to write about his emotions and our email replies were always short. The data thus consist mainly of a monologue, with just a few playful prompts and encouragements from the researcher to keep sending updates. Some examples include:

a. Hi Robert, thanks for the two emails - I'll file them away as little diary updates. If you send one of these every two weeks or so we'll have a nice pool of information to work from. I trust you had a good pool expedition in Mallorca and are now salsa-ing through the streets of Barcelona.

b. Interesting times continue for your little venture (nice update on your old VC chums). Discrete question: don't you think it's a little too many balls to keep juggling with? Or are you just being very 'entrepreneurial'?

c. I guess that means you still haven't heard from [company name]... Ain't no fun being an entrepreneur. Maybe we should meet up at the end of the month... Take care.

We analysed our data following a life-narrative approach (Riessman 2002) which captures the longitudinal and fragmented aspects of the material. Seen from this perspective narratives are used by the narrator to cope with the fluid positioning that makes up identity work. Following a life-narrative approach, emotions and self-perceptions are not necessarily addressed directly and explicitly, but often organized in plots derived from disordered experiences (Gabriel 2008; Riessman 2002), and thereby often expressed through shifts in tensions, moods and motivations (Gabriel 2012). When coding Robert's emails we therefore did not just note when Robert directly spoke about his emotions, but also noted when there was a shift in the mood of the email; when irony was used; the discourse this seemed to centre around; and how he expressed his identity through this. To make sense of all the data, we conducted a first level coding in 
which we analysed the emails chronologically and categorised the material in a spreadsheet using seven data entry columns: 1) Date; 2) 'Robert speaking' (i.e. summary of email, verbatim quotes); 3) Comments (researchers' reflections); 4) Identity (secondary researchers' reflections); 5) Emotions (both directly referred to and when we sensed a change in the mood of the email); 6) Discourses (broadly defined as what general discourses or logic the email tended to draw on); and 7) Factors (explanatory factors). The spreadsheet comprised 32 pages, and an excerpt is shown below to give the reader an idea of the format of the data analysis.

\section{$\underline{\text { Insert Table } 1 \text { 'Data coding sheet excerpt' about here }}$}

The overview contained in the spreadsheet made it possible for us to focus on Robert's shifts in identity and how he emotionally managed these shifts. Our analysis comprised three steps: First, we identified the liminal aspects of Robert's identity work; we then looked for emotional reflexivity in the way emotions were uttered and employed; and we finally linked this back to liminality to analyse what influence emotional reflexivity seemed to have on Robert's experience of liminality. To identify the liminal aspects of his identity work, we used the identifiers of liminality acknowledged in the literature. These include: confusion, contradicting opinions, multiple identity positions, feeling out of control, identity struggle (e.g. Beech 2011; Czarniawska and Mazza 2003). In the second step of the analysis, we followed Burkitt's (2012) definition of emotional reflexivity, as we did not only code when emotions were uttered, but also looked for moments when Robert used emotions to interpret his situation. This often implied emotional ambiguity, irony and sarcasm, which all became indicators of emotional reflexivity. A typical example would be a statement like, 'I am not a good entrepreneur; je suis un bit loopy'. In the final step of the analysis we then looked at what influence this emotional reflexivity seemed to have on the way Robert experienced the liminality that characterized his 
narrative. Here it seemed his reflexive identity work made it possible for him to create temporary exits from liminality, something which was indicated by the emails carrying a mood of resolution or redemption. These exits were, however, temporary and often to a great degree simulated in his narrative, which was also why they quickly disappeared again.

Eighteen months in Robert's life - a narrative analysis of identity work and emotional reflexivity

Things to do.

Marketing flier.

Order European data.

Redesign database to accommodate EU data.

Think about hiring someone to build it properly.

Check email tonight to see if [company name] have come back.

Make tea.

Go to pub for a drink in Quiet Corner.

Go to bed.

Get up and go back home.

Go to bed again.

I wished I knew what I was doing. Or why. Do I enjoy this? Enough?

(email, no subject)

\section{Identity work as liminal struggle}

In line with our analytical steps explained above, we begin by showing how Robert's daily identity struggles are characterised by liminality. As we have indicated in the earlier part of this paper, liminality scholars from both anthropological and organizational backgrounds emphasize the role of external triggering events in entering this liminal condition. However, when we analysed Robert's stories we came to understand the complexity and non- 
sequentiality of the process. The diary entry below gives a first glimpse of the liminal complexity in Robert's identity struggle:

Am feeling very fed up and disappointed in myself today. I had a particularly bad night, lots of dreams that kept waking me up. Actually one of those nights where you feel like you have dozed the whole way through. Anyway, the point is this: I got up at five having dreamt/decided that I needed to take more risks. I set off with great intentions, although no great idea what this may be or form it may take, and took no risks at all. (email, subject: risky business)

Right from the outset Robert's narrative highlights a number of interesting points. First, we can immediately identify Robert's multiple identity positions which he struggles to reconcile: the present 'me' who considers himself able to take risks, the 'non-me' position that has not taken them, and the possible self who not only speculates about risks but actually puts these into action, too. We can see that Robert is finding himself 'betwixt and between' as the identity positions clash: his idea of himself is at odds with how his days unfold. Robert first mobilises a new possible imaginary self that takes more risks. This self appears in a period when Robert's AMA venture has been struggling to take off. Robert positions this new identity against a current 'non-me' position and uses an imaginary other (risk taking and successful) to reflect on and judge the outcome of the identity performance. The displacement of identity position into the future allows for agency ('setting off with great intentions') but the incompatibility with the current non-me position ('no great idea' about the form) jeopardises the move. This situation can be understood as Robert trialling a new identity and reflecting upon it in order to situate the experience within the expected entrepreneurial behaviour. The emotional component is clearly visible through Robert's assigning of subjective value to competing identities, and his reflexive account is narrated through this lens. Emotions thereby seem key to the way he reflexively makes sense of liminality. 
However, this process is not necessarily caused by negative events. Liminality also seems to characterize the identity work he performs when he receives positive feedback from the social context, as in the diary entry below where he has just landed a re-selling contract, which he needs in order to make a living but where his heart is not really in it:

To clarify. The sale I made yesterday to [company name]. They are buying from me a product made by someone else. Which makes me technically a re-seller. Some may call it lazy, but re-seller is nicer. They are paying more than it cost me. Assuming everything goes ahead and they are happy, [company name] has also agreed to pay an annual licence - which is very nice as I get recurring income. (email, subject: Re: Infinity Group: Press Announcement)

Robert has mixed feelings about this sale as it was not the product that he has created and considers his core business. On the one hand, we noted how he adjusts his re-seller identity from 'lazy' to 'ingenious idea that creates money easily' as he states a little later in the same email; this modification allows Robert to continue this identity performance by pursuing this line of business (although it is not the one he prefers). On the other hand, elsewhere in the emails Robert's reflections show that this identity is nevertheless problematic and in conflict with his alternative desired identity, which is being the successful entrepreneur who makes money out of his core product, his own invention:

I try to suppress the guilt of reselling something that only cost me $£ 1,000 \ldots$ Perhaps I should think about what I really want. (email, no subject)

This example of a tension between multiple identities indicates that Robert experiences a 'holding' environment, which can be interpreted as a middle period of negotiation between conflicting incompatible identities. According to Ibarra (2007) entrepreneurs are prone to 
prolonged conflicts of identity because they often pursue multiple projects at the same time. The intertwinement of multiple identities is further visible in one of the later emails:

The wonderful weird world of infinite gloom has a meeting on Tuesday with [client name omitted] re a possible outsourcing contract - see below

More exciting is I have finally got back into [company name] and they have agreed to meet on Monday next at noon. Ding. To talk about AMA. Ding Dong

I spoke with [client 2 name omitted] - the other broker interested in AMA and they are still to make a decision. First cometh first serveth? (email, subject: FW: Meeting confirmation)

The double success of getting interest from corporate clients helps Robert to confirm his preferred entrepreneurial identity narrative, thus temporarily resolving existing tensions. Again, Robert uses specific linguistic strategies to position himself in the social context. We noted, for example, the use of irony ('first cometh first serveth' or 'ding dong') to re-align his identity narrative by dismissing previous difficulties. In doing so, he dismisses doubts about his preferred identity because it is always there - only sometimes it gets obscured by daily 'boring' activities. Robert does this not only at the point of ceremonial passage, but continues to provide these reaffirmations throughout his diary:

Not to gloat but to let you know that what intrigues me, and may surprise you, is that I am not at all excited about it, I do enjoy working on an idea and may even manage a smile when I win a deal but it very soon fades. The kick is pitting my wits against the world and occasionally winning (email, subject: Postcard)

Characterizing his business venture as 'pitting my wits against the world and occasionally winning' is something that surfaces regularly in both emails and interviews. The longitudinal nature of these examples indicates that navigating liminality is for Robert not simply a case of 
enter-resolve-conclude, as most current liminality literature drawing on van Gennep's original concept seems to suggest (Beech 2011; Conroy and O'Leary-Kelly 2014; Garsten 1999). Instead, rather than just being a temporary phase, liminality for Robert seems to be a perpetual condition for his identity work, where everyday identity performances produce a self-narrative through inner dialogue between various temporal and fragmented identities. This dialogue involves emotions because the liminal is 'not here nor there', but rather is suspended in a multiplicity of positions and therefore it is impossible to establish a definite relationship between these and their context (Burkitt 2012). This inability manifests itself as a rollercoaster of emotions, which has been previously acknowledged (but not analysed) by Czarniawska and Mazza (2003) and Beech (2011).

\section{Emotional reflexivity in identity work,}

Emotions are clearly verbalised throughout Robert's emails, both in the explicit referral to the emotions he feels and in the very mood of the emails. The most intense emotional reflections are often centred around the fact that life as an entrepreneur does not turn out as he expected it to be: busy, exciting and successful; a 'performance/pleasure apparatus' (Szeman 2015, 482). Just to let you know that I am back in the cell after a very enjoyable week in Mallorca. The first few days were a struggle. Nothing to do! Anyway I managed to get into the groove when I found the local tapas bar (...) My little business seems to have survived without me - although I suppose I took it with me. So far since coming back on Saturday night I have written a contract and put up an extravagant quote for an insurance aggregations model... I can't find out whether I am the right person and justify me and my prices. Oh well, it's done now. (email, subject: struggle)

In this quote Robert makes use of direct emotional references as well as the email itself having an ironic, moody feel. In Robert's case, such a strong emotional reaction is closely tied to the 
nature of his preferred entrepreneurial identity where 'being busy' brings a displacement of gratification from future outcomes to the present as he fantasises about his business success. Such displacement is possible as Robert reflexively tries to align his identity narrative to a future desired identity. His use of emotional language is therefore not just a response to his situation, but is embedded in the very reflection of his situation, which at the same time constructs his complex identity. This example shows the necessary internal dialogue that Robert needs to have with himself to achieve narrative coherency of identity. Having nothing to do does not fit into this narrative, forcing him to re-evaluate it.

As months go by, Robert's business still mainly consists of re-sells or consulting and not his AMA product sales. Because of this, he gets very bored with his work and continuously questions his identity as he struggles to fit this situation into possible scenarios leading to his desired future self:

No fun at all. I did conclude my little resale commission deal yesterday. $£ 1400$. Why do I do these things? Am I a deal junky? (email, subject: Re: Risky Business)

Robert is generally frustrated with the fact that his business venture always seems to end up in 're-sells', 'low-hanging fruit', 'no-brainers', 'quick-fixes' as he refers to them over and over again. In the email below he experiences desolation as he reflexively assesses the reality of entrepreneurial life, which is not how he imagined it to be:

I really enjoyed the weekend so much that I loathed to return to 'reality' (well my reality anyway). This happens every now and again, sometimes for good reason, sometimes for none - so maybe it is a cross to bear. Anyway I have done nothing this week. No interest. Can't be bothered. Fed Up. Don't care (and yes, I use this phrase advisedly). Regrettably this means that what I know I must do is piling up against the gate and of course it will not be denied. And no, that does not help either. Bugger. 
Seems that I am having a ramble tonight. What the hell am I doing sitting here on a Friday night? Do you think there is a market for a dating agency for those in essentially solitary professions like academia and entrepreneurs? (email, subject: Fed Up)

Through narratives like this, Robert attempts to warn the receiver of the email not to expect too much in order not to put too much pressure on himself out of fear of failure. To deal with such a threat to his preferred identity he manages to build self-support for the alternative, less preferred, re-seller identity, something that was previously established as an unwanted non-me position:

If they bite I am going to ask for 100k. This year. And a chunk more next and subsequent years for data updates. Of course I feel very bad about this. Mainly because the data is essentially in the public domain, at least if you have the phone number to the company in the USA and a credit card with a very small limit! On the legal side I have checked that I can resell the data, and indeed I can. Remarkably having bought the data once I can resell any number of times for $\mathrm{NO}$ extra cost. Ha ha ha. HAHAHAHAHHAHHAHHAH. (email, subject: RE: Stressed)

Contrary to the examples discussed earlier in this paper, here the possibility of easy financial gain is portrayed as 'winning' in 'pitting my wits against the world'. Through the use of irony - 'of course I feel very bad about this' - Robert positions this identity outside of the preferred identity narrative and as not a perceived 'real' self. This narrative is, however, complicated by annoyance or even guilt that he cannot fully enjoy an easy financial gain. To deal with this contradiction, Robert often offers a supporting narrative where he tries to convince his interlocutor - and himself - that the possibility of financial gain does not excite him. Instead, what does drive him forward is the possibility of creating something new: 
And then there is the next great idea. Haven't had it yet but I am sure I will. (email, subject: Flood latest)

Robert's emotional reactions are not just responses to a difficult situation, but are also deeply embedded in the interpretation of what he goes through and who he is. This often results in simultaneous conflicting emotional displays. The example below is a continuation of one of the emails above where Robert spends half of the email explaining how stressed he is and how he cannot complete any of his tasks, but then he switches his tone dramatically to show how excited he is about a new business possibility:

Business is interesting ... The meeting went very well, although the person I spoke to was the wrong person. The model worked well, they were very impressed that One Man and His Dog Ventures had done what a multi \$billion company thought was impossible. (email, subject: stressed)

This can be considered a clear example of a turning point as reported by liminality scholars (viz. van Gennep's 'ceremonial passage'). However, the interest of a new corporate client in Robert's product does not offer him the needed resolution. Robert's narrative is laid out in such a way that he detaches himself from the previous reseller position, but he does not allow himself yet to recognise his 'new' (and preferred) identity as AMA provider. As such, he finds himself in the 'betwixt and between original positions by law and custom' described by Turner (1977, 95). Yet, this is at the same time an obvious attempt at communicating through emotional reflexivity (Burkitt 2012), as Robert continuously performs identity work by negotiating his position between fantasy and reality, whilst engaging in emotional reflections on this. When unable to confirm his preferred entrepreneurial identity, the liminality of his identity work is fore-grounded again so that he can temporarily suspend that narrative in an effort to preserve 
it. By reflexively negotiating several identity positions at the same time, he can 'pick' another identity as a temporal substitute for the preferred one.

\section{Emotional reflexivity as temporary exit from liminality}

Robert's identity narrative is characterised by a number of tensions typical of the experience of liminality. Often they are displayed not only as an emotional rollercoaster over time, but also as strong tensions within one diary entry:

I am at the risk of giving you entirely the wrong impression about me and my little business. It is not always this exciting. Indeed the opposite. However... I made another sale yesterday!

And of course no contract. No scope of works. No target dates. No end dates. A shake of the hands. So he will get a lot more than he thought he was ever going to get (I give good service and always over deliver), and I will work harder than I need to just because I am a bit of a lump like that. But it is something that interests me and won't be a chore to do. (email, subject: Day 806 in the Big Brother House)

This email clearly shows that it is not just 'emotions' that guide the identity process, but rather an 'emotional reflexivity' (Burkitt 2012) as Robert engages in a reflexive negotiation of how he feels about his possible identities. The tensions therefore become constructive in that they spark off a new goal, a new venture idea. This leads him straight back to the euphoria and excitement of a new challenge, only to be eventually disappointed with its outcome ('and of course no contract'). Making a sale then becomes a ceremonial closure, but rather than a real exit from liminality and emotional instability, it is a temporary resolution of one of the tensions. To deal with this uncertainty, Robert resolves to set up yet another business in an effort to 
displace the liminal resolution into the future, thus offering a temporary stability by 'setting up' a temporary alternative identity:

Infinite Recruitments has been set up... sounds grand but in reality it has come about completely by chance, cost me three phone calls and about 10 minutes of thinking. $10 \%$ first year salary as commission makes this huge effort all worthwhile. (email, subject: Postcard)

This exercise is necessary to help Robert maintain an illusion of the possibility of his entrepreneurial identity. Otherwise he would have been forced to settle for being a small business owner, which does not match his idea of who he wants to be. In other words, liminality becomes a condition of possibility. As such, Robert begins to fantasize in order to give himself a raison d'être. In this sense his identity is always displaced towards the future, effectively blurring the line between what is 'fake' and what is 'real'. However, this is not unproblematic as the constant ups-and-downs make him doubt himself:

I have been trying to understand my emotions in all of this, and not sure I am getting anywhere. I am sure I am right to continue to question why I am doing this whilst not really being sure at the outcome or consequences. I keep coming back to the same issue of liking to pit my wits against the world and (occasionally) winning. But have I just hit on this idea and can't let go? Am I kidding myself? Not sure. Yes. No. Don't know. (email, subject: Before \& after)

At first sight Robert's emotional language might seem unproductive and a consequence of doubting himself as an entrepreneurial actor. However, if we consider this struggle from the point of view of emotional reflexivity, we can see that Robert's emotional ups-and-downs are in fact what help him construct himself as an entrepreneur. The destruction of defining himself in terms of non-me positions also seems to be creative, because when one fantasy is destroyed the struggle helps to produce a new one. As such Robert's emotional expressions are not an 
outcome of failed identity work, but rather the corner stone in his identity work as he tries to reconcile the fantasy and reality of his lived liminal experience and tries to situate himself in that context. In this sense, the experience of liminality is necessary because it enables experimentation with new identities before incorporating them into a larger identity narrative, as the following email illustrates:

I know I enjoy what I do which certainly helps. I also know I tend to pursue what interests me rather than what is obviously a money earner. Does this make me an entrepreneur at all? I may be entrepreneurial but is that the same? But I struggle if the question is extended to what am I doing this for. Kudos? Ego? Arrogance? Don't know. I am lucky that things have been sufficiently good that I have money left at the end of the month. (email, subject: Entrepreneur?)

In short, the liminal condition of entrepreneurship provides Robert with the possibility to experiment with an entrepreneurial identity that is at the same time creative/playful and moody/dark. The exits in which he reconciles himself either with a re-seller identity or allows himself to enjoy his entrepreneurial successes are temporary emotional breaks from the constant self-reflection. In other words, liminality is the 'normal' condition for Robert, the exits are temporary. Emotional reflexivity is therefore not about providing emotional clarity, but rather a construction of a temporary break from liminality.

\section{Concluding Discussion: liminality, emotional reflexivity, and the political}

The moment of the political is... linked to the surfacing of a constitutive lack within our fantasmatic representations of society... The political is associated thus with the moment of contingency and undecidability marking the gap between the dislocation of one socio-political identification and the creation of the desire for a new one... (Stavrakakis 1999, 75). 
A key objective of this paper has been to introduce the concepts of liminality and emotional reflexivity, which have been mainly developed in the organization studies literature, to consider the complexities of identity work in an entrepreneurial setting in novel ways, thus teasing out and elaborating interdisciplinary connections between organization and entrepreneurship studies. In this, we follow Hjorth et al.'s (2015) suggestion that a broad set of research problems in entrepreneurship studies can benefit from conceptual developments in organization studies. Our analysis has shown that navigating liminality is not always a simple case of enter-resolveconclude, as much of the literature on identity and liminality seems to suggest. In this literature, liminality typically is seen as a phase or positioning in time and space, and dominant conceptions direct attention towards people's pursuit of coherence in their identity work (Alvesson and Wilmott 2002, Henfridsson and Yoo 2014). Furthermore, Robert's emails about his life and business certainly 'belie the narrative direction and coherence that concepts like entrepreneurship give to it' (Popp and Holt 2013, 52). In our study of his identity work we found that 'epiphanies' and identity shifts melt together in complex and non-sequential ways and make up a perpetual liminal condition for identity work. Robert permanently displaces his desired identity into the future in an attempt to safeguard it from the everyday struggles that do not fit into the narrative that he is trying to create for himself. By examining the longitudinal dynamic role emotional reflexivity plays in the identity work of an entrepreneur experiencing perpetual conditions of liminality, this paper has tried to respond to the call for more empirical research examining insecure, ambiguous and critical identity talk (Coupland and Brown 2012, Ybema et al. 2009). Indeed, as Glynos and Stavrakakis (2008, 266) suggest, 'by taking into account emotion... one may be able to reach a more thorough understanding of... both what fuels identification processes and what creates discursive fixity'. Such an understanding of what drives the identification process is vital in exploring the political dimensions of enterprise discourse. 
The enterprise discourse as perpetuated by academic research and by media representations of the entrepreneur is political in a straightforward way in that it masks and suppresses many important socio-political issues such as gender (e.g. Hamilton 2013) and class (e.g. Gill 2014), claiming that anyone can be an entrepreneur whilst simultaneously limiting entrepreneurial legitimacy. The dominant normative reading of entrepreneurship and enterprise culture where 'the bravery, the creativity and hard work shine through' (Drakopoulou Dodd et al. 2013, 80) is also strongly suggestive of a particular kind of subjectivity appropriate to the contradictions and uncertainties that attend life under $21^{\text {st }}$ century capitalism (Catlaw and Marshall 2018). The enterprise discourse 'interpellates' subjects who try to constitute a self through "a process of "identifying" with or "recognizing" oneself in a particular ideology', but they are never able to fully internalize and identify with this entrepreneurial self (Jones and Spicer 2005, 224). When for example the participants in Gill's study $(2014,63)$ 'expressed an entrepreneurial yearning that indicated they felt a sense of lack', this very 'lack' should be considered constitutive of the subject as it is precisely 'the space where the whole "politics" of identification takes place... the subject is always attempting to cover over this constitutive lack in the level of representation, through continuous identification acts' (Stavrakakis 1999, 35).

Identification with an ultimately unattainable entrepreneurial self is political in that this particular subjectivity offers 'a common sense way of navigating the inevitable, irreproachable, and apparently unchangeable reality of global capitalism' (Szeman 2015, 473). Calls to 'de-link entrepreneurship from capitalism' (e.g. Williams and Nadin 2013, 552) and find an 'entrepreneurial condition' that breaches 'the singular pursuit of economic returns under a compulsion that life might somehow be organized differently' as outlined in the call 
for papers for this special issue (Hjorth et al. 2016, 602), perhaps are in danger of ignoring the political point that 'entrepreneurship' is not a neutral term in society at large; it relates to political philosophies and to existing tensions and contradictions that striate the social (Watson 2013a). We have to conceive of the yearning that 'life might somehow be organized differently' as always-already part of the fantasmatic set-up of the contemporary capitalist political economy (Catlaw and Marshall 2018). But how then does one 'go on' in the face of such a hegemonic discourse ${ }^{4}$ ?

We have shown in some detail how an individual tries to impose his own order on life when confronted with the mechanisms of subject formation inherent in modern entrepreneurship discourse by engaging in various identification acts. Berlant's $(2011,24)$ theorization of 'cruel optimism' as 'a relation of attachment to compromised conditions of possibility whose realization is discovered either to be impossible, sheer fantasy, or too possible and toxic...' is a productive way of understanding the nature of Robert's entrepreneurial identity work when faced with a constant lack (see also, Muhr and Kirkegaard, 2013). As they recognize the compromised conditions of possibility under $21^{\text {st }}$ century capitalism, individuals actively come to aspire to 'living in an impasse', Berlant $(2011,8)$ suggests. Through emotional reflexivity, Robert could experiment and play with multiple identities which characterize the liminality of contemporary modern work life. Emotional reflexivity, then, offers the opportunity to struggle with the complex and contradictory constellation that is entrepreneurship discourse, without outright rejecting this discourse. In Robert's case this

\footnotetext{
${ }^{4}$ Enterprise discourse is hegemonic in that we are constantly forced to position ourselves in relation to it; either by trying it on for size, looking for an 'outside', or trying to find a sociopolitical identification that stands in opposition.
} 
was clear in the way the discourse of enterprise was constantly both confirmed and contested, but ultimately underpinned his subjectivity.

\section{References}

Alvesson, M., and Willmott, H. 2002. "Identity regulation as organizational control: Producing the appropriate individual." Journal of Management Studies 39 (5): 619-44.

Alvesson, M., Ashcraft K.L., and Thomas, R. 2008. "Identity matters: Reflections on the construction of identity scholarship in organization studies." Organization 15 (1): 528.

Anderson, A.R. 2005. Enacted Metaphor: "The Theatricality of the Entrepreneurial Process." International Small Business Journal 23 (6): 587-603.

Anderson, A.R., and Warren, L. (2011). “The entrepreneur as hero and jester: Enacting the entrepreneurial discourse.” International Small Business Journal 29 (6): 589-609.

Barbalet, J.M. 1998. Emotion, Social Theory, and Social Structure - A Macrosociological Approach. Cambridge: Cambridge University Press.

Beech, N. 2008. "On the nature of dialogic identity work." Organization 15 (1): 51-74.

Beech, N. 2011. "Liminality and the practices of identity reconstruction." Human Relations 64 (2): 285-302.

Berlant, L.G. 2011. Cruel Optimism. Durham, NC: Duke University Press.

Burkitt, I. 2012. "Emotional reflexivity: Feeling, emotion and imagination in reflexive dialogues." Sociology 46 (3): 458-472.

Catlaw, T.J., and Marshall, G.S. (2018). "Enjoy your work! The fantasy of the neoliberal workplace and its consequences for the entrepreneurial subject." Administrative Theory \& Praxis 40 (2): 99-118.

Clarke, J., and Holt, R. 2010. "The mature entrepreneur: A narrative approach to entrepreneurial goals." Journal of Management Inquiry 19 (1): 69-83.

Clarke, J., and Holt, R. 2017. "Imagery of ad-venture: Understanding entrepreneurial identity through metaphor and drawing." Journal of Business Venturing 32 (5): 476-497.

Conroy, S., and O'Leary-Kelly, A.M. 2014. "Letting go and moving on: Work-related identity loss and recovery." Academy of Management Review 39 (1): 67-87.

Costas, J., and Fleming, P. 2009. "Beyond dis-identification." Human Relations 63 (3): 353378.

Coupland, C., and Brown, A.D. 2012. "Identities in action: Processes and outcomes." Scandinavian Journal of Management 28: 1-4.

Czarniawska, B., and Mazza, C. 2003. "Consulting as a liminal space.” Human Relations 56 (3): 267-290. 
Daniel, E., and Ellis-Chadwick, F. 2016. "Entrepreneurship and liminality: the case of selfstorage based businesses." International Journal of Entrepreneurial Behavior \& Research 22 (3): 436-457.

Daskalaki, M., Butler, C. L., and Petrovic, J. 2016. "Somewhere In-Between: Narratives of Place, Identity, and Translocal Work". Journal of Management Inquiry 25 (2): 184198.

Daskalaki, M., Hjorth, D., and Mair, J. 2015. "Are Entrepreneurship, Communities, and Social Transformation Related?” Journal of Management Inquiry 24 (4): 419-423.

Drakopoulou Dodd, S., Jack, S., and Anderson, A. R. 2013. "From admiration to abhorrence: the contentious appeal of entrepreneurship across Europe." Entrepreneurship \& Regional Development 25 (1-2): 69-89.

Egan-Wyer, C., Muhr, S. L., and Rehn, A. 2018. "On startups and doublethink: Resistance and conformity in negotiating the meaning of entrepreneurship". Entrepreneurship and Regional Development 30 (2): 58-80.

Gabriel, Y. 2008. Organizing Words: A Thesaurus for Social and Organizational Studies. Oxford: Oxford University Press.

Gabriel, Y. 2012. "Organizations in a state of darkness: Towards a theory of organizational miasma." Organization Studies 33 (9): 1137-1152.

Garsten, C. 1999. "Betwixt and between: Temporary employees as liminal subjects in flexible organizations." Organization Studies 20 (4): 601-617.

Gartner, W.B. 1988. “'Who is the entrepreneur?' is the wrong question”, American Journal of Small Business 12 (4): 11-32.

Gartner, W.B. 2010. An Entrepreneurial Jeremiad. In Entrepreneurial Narrative Theory Ethnomethodology and Reflexivity, ed. W. Gartner, 1-13. Clemson, SC: Clemson University Digital Press.

Gill, R. 2014. "“If you're struggling to survive day-to-day': Class optimism and contradiction in entrepreneurial discourse." Organization 21 (1): 50-67.

Glynos, J., and Stavrakakis, Y. (2008). "Lacan and political subjectivity: Fantasy and enjoyment in psychoanalysis and political theory." Subjectivity 24 (1): 256-274.

Hamilton, E. 2013. "The discourse of entrepreneurial masculinities (and femininities)." Entrepreneurship \& Regional Development 25 (1-2): 90-99.

Hamilton, E. 2014. "Entrepreneurial Narrative Identity and Gender: A Double Epistemological Shift.” Journal of Small Business Management 52 (4): 703-712.

Henfridsson, O., and Yoo, Y. 2014. "The liminality of trajectory shifts in institutional entrepreneurship." Organization Science 25 (3): 932-950.

Hjorth, D., Holt, R., and Steyaert, C. 2015. "Entrepreneurship and process studies." International Small Business Journal 33 (6): 599-611.

Hjorth, D., Holt, R., Fernandez, P., and Farias, C. 2016. "Organizational Entrepreneurship and the Political: Call for Papers." Entrepreneurship \& Regional Development 28 (78): 601-604.

Holmes, M. 2010. “The emotionalization of reflexivity.” Sociology 44 (1): 139-154. 
Ibarra, H. 2007. "Identity transitions: Possible selves, liminality and the dynamics of voluntary career change." INSEAD working paper 2007/31/OB.

Jarvis, L. 2016. "Identification, intentions and entrepreneurial opportunities: an integrative process model." International Journal of Entrepreneurial Behavior \& Research 22 (2): $182-198$.

Johnsen, C.G., and Sørensen, B.M. 2014. “'It's capitalism on coke!': From temporary to permanent liminality in organization studies." Culture and Organization, 21 (4): 321337.

Jones, C., and Spicer, A. (2005). "The sublime object of entrepreneurship." Organization 12 (2): 223-246.

Kašperová, J. and Kitching, J. 2014. "Embodying entrepreneurial identity". International Journal of Entrepreneurial Behavior \& Research 20 (5): 438- 452.

Larty, J., and Hamilton, E. 2011. "Structural approaches to narrative analysis in entrepreneurship research: Exemplars from two researchers." International Small Business Journal 29 (3): 220-237.

Leitch, C.M., and Harrison, R.T. 2016. "Identity, identity formation and identity work in entrepreneurship: conceptual developments and empirical applications." Entrepreneurship \& Regional Development 28 (3-4): 177-190.

Lemmergaard, J., and Muhr, S.L. 2012. "Golfing with a murderer: Professional indifference and identity work in a Danish prison." Scandinavian Journal of Management 28 (2): $185-195$.

Lemmergaard, J., and Muhr, S.L. 2013. "Broadening the critical leadership repertoire: Emotions, toxicity and dysfunctionality.” In: Lemmergaard J., Muhr S.L. (eds) Critical Perspectives on Leadership - Emotion, Toxicity and Dysfunction, 3-28. Cheltenham, UK: Edward Elgar.

Muhr, S.L., and Kirkegaard, L. 2013. "The dream consultant: Productive fantasies at work." Culture and Organization 19 (2): 105-123.

Muhr, S. L., Pedersen, M. and Alvesson, M. 2012 "Work-load, passion and fun: Problems of balancing self-exploitation and self-exploration in work-life." Research in the Sociology of Organization 37: 193-220.

Mumby, D.K., and Putnam, L. 1992. "The politics of emotion: A feminist reading of bounded rationality." Academy of Management Review 17 (3): 465-486.

Popp, A., and Holt, R. 2013. "Entrepreneurship and being: the case of the Shaws." Entrepreneurship \& Regional Development 25 (1-2): 52-68.

Riessman, C.K. 2002. "Analysis of personal narratives.” In: Gubrium, J.F., and Holstein J.A. (eds) The SAGE Handbook of Interview Research, 367-379. Thousand Oaks, CA and London: Sage.

Sørensen, B.M. 2008. “'Behold, I am making all things new': The entrepreneur as savior in the age of creativity." Scandinavian Journal of Management 24 (2): 85-93.

Schaefer, S., and Paulsson, A. 2013. "The emotional rollercoaster: Leadership of innovation and the dialectical relationship between negative and positive emotions." In: Lemmergaard J., and Muhr S.L. (eds) Critical Perspectives of Leadership: Emotion, Toxicity and Dysfunction, 105-126. Cheltenham: Edward Elgar. 
Stets, J. 2012. "Current emotion research in sociology: Advances in the discipline." Emotion Review 4 (3): 326-334.

Steyaert, C. 2005 'Entrepreneurship: in between what? On the 'frontier' as a discourse of entrepreneurship research." International Journal of Entrepreneurship and Small Business 2 (1): 2-16.

Stavrakakis, Y. (1999). Lacan and the political. Oxford: Routledge.

Szeman, I. 2015. "Entrepreneurship as the New Common Sense.” South Atlantic Quarterly 114 (3): 471-490.

Thomas, R. 2009. "Critical management studies on identity: Mapping the terrain.” In: Alvesson M., Bridgman T., and Willmott, H. (eds) The Oxford Handbook of Critical Management Studies, 166-185. Oxford: Oxford University Press.

Thomas, R. and Davies, A. 2005. "Theorizing the micro-politics of resistance: New public management and managerial identities in the UK public services." Organization Studies 26 (5): 683-706.

Turner, V. 1967. The Forest of Symbols: Aspects of Ndembu Ritual. Ithaca, NY: Cornell University Press.

Turner, V. 1974. Dramas, fields and metaphors: Symbolic action in human society. Ithaca, NY: Cornell University Press.

Turner, V. 1977. The Ritual Process. Ithaca, NY: Cornell University Press.

van Gennep, A. 1960 [1909]. The Rites of Passage (M.B. Vizedom and C.L. Caffee, trans.). London: Routledge and Kegan Paul.

Watson, T.J. 2013a. "Entrepreneurial action and the Euro-American social science tradition: Pragmatism, realism and looking beyond 'the entrepreneur'." Entrepreneurship \& Regional Development 25(1-2): 16-33.

Watson, T.J. 2013b. "Entrepreneurship in action: bringing together the individual, organizational and institutional dimensions of entrepreneurial action." Entrepreneurship \& Regional Development 25 (5-6): 404-422.

Williams, S. 2010 "A Rhetorical Theory of Transformation in Entrepreneurial Narrative: The Case of The Republic of Tea." In: Entrepreneurial Narrative Theory

Ethnomethodology and Reflexivity, ed. W. Gartner, 15-31. Clemson, SC: Clemson University Digital Press.

Williams, C.C., and Nadin, S.J. 2013. "Beyond the entrepreneur as a heroic figurehead of capitalism: Re-representing the lived practices of entrepreneurs." Entrepreneurship \& Regional Development 25(7-8): 552-568.

Ybema, S., Keenoy, T., Oswick, C., Beverungen, A., Ellis, N., and Sabelis, I. 2009. “Articulating identities." Human Relations 62 (3): 299-322.

Ziegler, M., Rosenzweig, B., and Ziegler, P. 1994. The republic of tea: The story of the creation of a business, as told through the personal letters of its founders. New York: Doubleday. 
Table 1: Data coding sheet excerpt

\begin{tabular}{|c|c|c|c|c|c|c|}
\hline DATE & ROBERT SPEAKING & COMMENTS & IDENTITY & EMOTIONS & DISCOURSES & FACTORS \\
\hline $7 / 7$ & $\begin{array}{l}\text { They are buying from me a product made by } \\
\text { someone else. Which, makes me in technical terms a } \\
\text { re-seller. Some may call it lazy but re-seller is nicer. } \\
\text { Assuming everything goes ahead... I get recurring } \\
\text { income. }\end{array}$ & $\begin{array}{l}\text { Calling himself a re-seller } \\
\text { to make it more legitimate } \\
\text { (although conscious) }\end{array}$ & $\begin{array}{l}\text { Constructing a non-me } \\
\text { position } \\
\text { Positive spin on a non- } \\
\text { me identity }\end{array}$ & $\begin{array}{l}\text { Slightly guilty about } \\
\text { being lazy }\end{array}$ & $\begin{array}{l}\text { Legitimising his } \\
\text { work and position }\end{array}$ & $\begin{array}{l}\text { Part of the } 1^{\text {st }} \\
\text { sale }\end{array}$ \\
\hline $7 / 7$ & $\begin{array}{l}\text { Infinite Recruitments has been set up... } \\
\text { sounds grand but in reality it has come about } \\
\text { completely by chance, cost me three phone calls and } \\
\text { about } 10 \text { minutes of thinking. } 10 \% \text { first year salary as } \\
\text { commission makes this huge effort all worthwhile. }\end{array}$ & $\begin{array}{l}\text { Can't say no } \\
\text { Opportunity is } \\
\text { everywhere } \\
\text { Little effort, money } \\
\text { guaranteed }\end{array}$ & $\begin{array}{l}\text { Alternative identities to } \\
\text { be summoned as needed }\end{array}$ & Need to justify himself & $\begin{array}{l}\text { Seeing } \\
\text { opportunities } \\
\text { everywhere } \\
\text { Importance of } \\
\text { image }\end{array}$ & $\begin{array}{l}\text { Easy } \\
\text { opportunity } \\
\text { came up }\end{array}$ \\
\hline $7 / 7$ & $\begin{array}{l}\text { I entertain lots of different ideas. Not necessarily the } \\
\text { brightest light but certainly what interests and excites } \\
\text { me most }\end{array}$ & $\begin{array}{l}\text { Feels as if he should be } \\
\text { acting differently, that it's } \\
\text { not how it's 'supposed to } \\
\text { be' }\end{array}$ & $\begin{array}{l}\text { Tension between } \\
\text { preferred identity and } \\
\text { lived reality }\end{array}$ & $\begin{array}{l}\text { Guilty of doing what he } \\
\text { likes, rather than what } \\
\text { he 'should' }\end{array}$ & $\begin{array}{l}\text { What it means to be } \\
\text { entrepreneur: one } \\
\text { amazing idea to } \\
\text { pursue }\end{array}$ & $\begin{array}{l}\text { Met last } \\
\text { year's revenue } \\
\text { target in July }\end{array}$ \\
\hline $8 / 7$ & $\begin{array}{l}\text { Thinking about buying. Which is excellent news. But } \\
\text { probably means I didn't charge enough, or at least } \\
\text { could have got away with more. Or is that just being } \\
\text { greedy? Good lesson for the future. I'm not unhappy } \\
\text { with what I put up so mustn't complain too loudly. }\end{array}$ & $\begin{array}{l}\text { Greed } \\
\text { Everything's a bit of a } \\
\text { gamble and luck game }\end{array}$ & $\begin{array}{l}\text { Insecurity even about } \\
\text { promise of realisation } \\
\text { of preferred identity } \\
\text { Reflexive process }\end{array}$ & $\begin{array}{l}\text { Guilt for being greedy } \\
\text { Insecurity }\end{array}$ & $\begin{array}{l}\text { What is it that he } \\
\text { 'should' be? }\end{array}$ & $\begin{array}{l}\text { Client } \\
\text { interested }\end{array}$ \\
\hline $13 / 7$ & $\begin{array}{l}\text { Pie } 1 \text { The problem I am addressing (no pun intended) } \\
\text { with my GeoRite product is to help the underwriter } \\
\text { validate the data he gets from the Assured. Pretty } \\
\text { clever this. } \\
\text { Pie } 2 \ldots . \text { A very elegant solution even though I say so } \\
\text { myself. }\end{array}$ & $\begin{array}{l}\text { Very affirmative and } \\
\text { upbeat. Mood has shifted } \\
\text { significantly }\end{array}$ & $\begin{array}{l}\text { Pride in own product. } \\
\text { I am a saviour. } \\
\text { I am clever and I know } \\
\text { it }\end{array}$ & Pride, confidence & Saviour & Sale \\
\hline $20 / 7$ & $\begin{array}{l}\text { (reply to question what's new) I'm under enough } \\
\text { pressure without having to do "stuff' to make your } \\
\text { research better! }\end{array}$ & $\begin{array}{l}\text { Bit taken aback with } \\
\text { aggressive response - be } \\
\text { careful in future! }\end{array}$ & $\begin{array}{l}\text { Irritation with lack of } \\
\text { 'blood and guts' stuff }\end{array}$ & $\begin{array}{l}\text { Stress, pressure, easily } \\
\text { annoyed }\end{array}$ & & Pressure \\
\hline $16 / 8$ & $\begin{array}{l}\text { There are so many opportunities out there. Or is it } \\
\text { just me? I wish I knew what I was doing. This is all } \\
\text { still more fun than a driven urge to do anything. If I } \\
\text { was more aggressive then... well I'm not. }\end{array}$ & $\begin{array}{l}\text { Spotting opportunities } \\
\text { Luck/gamble } \\
\text { Self-reflexivity } \\
\text { Liminal }\end{array}$ & $\begin{array}{l}\text { Tension between } \\
\text { multiple identities }\end{array}$ & $\begin{array}{l}\text { Self-doubt; Insecurity } \\
\text { Guilty about having } \\
\text { fun, "should be } \\
\text { sacrifice" }\end{array}$ & $\begin{array}{l}\text { Sacrifice - Fun } \\
\text { How } \\
\text { entrepreneurship } \\
\text { should be }\end{array}$ & \\
\hline
\end{tabular}

